\title{
IEEE ISSCC (International Solid-State Circuits Conference) 2010 報告
}

山田浩（東芝）

\section{1.はじめに}

半導体集積回路技術に関する国際会議 IEEE ISSCC 2010 が， 2010 年 2 月 7 日〜2 月 11 日の 5 日間の日程で, 米国サンフランシスコで開催された。ISSCC は，集積回路 とシステム LSI に関する国際会議で, デバイス・プロセス 技術を主体にした IEDM (International Electron Devices Meeting) と共に, 半導体集積回路に関する分野では最も権 威ある国際会議の一つとして位置付けられている。ISSCC は，毎年 2 月上旬にサンフランシスコのマリオットホテル で開催される。57 回目の開催になった今回の会議でも, 半 導体集積回路の設計に関する最新の研究成果を世界中の企 業・研究機関・大学が競い合うと共に, 会議場では活発な 議論が行われた。

\section{2. 会議概要}

2010 年の会議は，世界的な経済不況の影響を受けた前回 の ISSCC 2009 (参加者数は約 2400 人程度) に比べると 10\%程度増加の 2600 2700 人程度の参加者数であった。 投稿論文数は, 638 本で, 論文数が落ち込んだ前回の ISSCC 2009 (582 本) に比べて 56 本増加して, 例年並みに回復し た。しかしながら，採択論文数は 210 本で, 前回の 203 本 と同等にまで絞り込んだため, 採択率は $32.9 \%$ と, 昨年に 比較して厳しくなった。

地域別の採択論文数では, 欧州が前回より 18 本増加の 70 本, 北米が同 23 本増加の 101 本と大幅に増加した。一方, アジアは 7 本減少の 66 本となり, 日本は 1 本減少の 32 本 で，国別では米国に次ぐ 2 位であった。ここ数年，1〜2本 採択されていた中国は 0 本, 台湾は前回の 17 本からほぼ半 減の 9 本であった。韓国は 5 本増加の 19 本で, 国別で 3 位 となり, 香港, シンガポール, インドはそれぞれ $1 \sim 2$ 本採 択されるという状況が継続した。

さらに, 組織別の採択論文数は, 米 Intel Corporation が 1 位で 13 本。アジア勢では, 東芝が 8 本で 3 位, 韓国 Samsung Electronics Co., Ltd. が 7 本で 5 位, 台湾大学が 6 本で 6 位, 韓国 Korea Advanced Institute of Science and Technology (KAIST) が 5 本で 9 位だった。

今回の本論文発表における一つの特徵は，採択論文数に 占める「企業」と「大学/研究機関」の比率が変化したこと

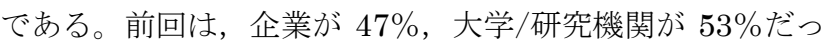
たが，今回は，企業が $51 \%$ なり，49\%の大学/研究機関 を逆転している。

このような中で開催された Plenary Session では, “Sensing the Future” という会議テーマに沿った 4 件の招 待講演が行われた。1 件目はドイツ Robert Bosch 社の Jiri Marek 博士から “MEMS for Automotive and Consumer Applications”の題名で講演が行われた。MEMS の歴史か ら，車載向けおよび携帯電話機など向けの応用，さらには
MEMS 信号読み出し回路の重要性や積層技術の実装例の紹 介と共に，MEMSによる発電を利用したセンサ・ネット・ ノードの実現に関する方向性が示された。2 件目は米国 TI 社の Greg Delagi 博士から “Harnessing Technology to Advance the Next-Generation Mobile User-Experience" の題名で講演が行われた。次世代携帯機器の信号処理速度 に対する要求を踏まえて, 電池容量と消費電力とのギャッ プを中心に議論を行い, 将来に対する期待を示した講演で あった。3 件目はソニーの鈴木博士から “Challenges of Image-Sensor Development” の題名で, フィルム写真を超 える CCD 性能の実現, 人間の視覚を超える CMOS 性能の 実現，それらの将来技術に関して，ソニーにおける CCD と CMOS イメージ・センサの開発事例を交えて講演が行われ た。4 件目は米国 Georgia Institute of Technology の James Meindl 博士から “Nanoelectronics in Retrospect, Prospect and Principle” の題名で, これまでのマイクロエレクトロ ニクス技術の発展, ITRS Roadmapによる近い将来技術の 方向性, さらに将来におけるナノエレクトロニクス技術を 実現するための原理が紹介された。なお, 招待講演の最後 には, 2009 年のノーベル物理学賞が, 光ファイバーの Kao 博士, CCD の Boyle 博士 Smith 博士に授与されたことに関 連して, 近年ノーベル物理学賞が, 基礎科学だけでなく集 積回路などの工学的に重要な貢献に対して授与されるよう になってきていることも紹介された。

なお, IEEE ISSCC では, 例年, 5〜10 年後の技術を視 野にした “Technology Directions” に関する Session が開 催されている。ISSCC 2010 では, “Designing in Emerging Technologies”, “Emerging Medical Applications”, “Directions in Health, Energy \& RF” の 3 セッションが 開催された。注目すべきトレンドは, “SoC (System on a Chip）を用いた医療モニタ・治療機器”, “有機回路のさら なる進歩と進化”, “3 次元 TSV (Through Silicon Via) 技術 の成熟”の 3 分野で, スペシャルトピックセッションとし て, CMOS 将来技術としての “Beyond CMOS - Emerging Technologies”, MEMS と回路技術の融合としての “Fusion of MEMS and Circuits” が開催され, 半導体素子と MEMS の異分野技術融合が注目分野として挙げられた。

\section{3. おわりに}

半導体素子と MEMS などの異分野融合により, 半導体集 積回路の応用範囲はこれまで以上に拡大しており, 今後, 新たな市場が創出されることは容易に想像される。

ISSCC2011 は, “Electronics for Healthy Living” のテ ーマで, 2011 年 2 月 20 日〜2 月 24 日の期間, 米国サンフ ランシスコ・マリオットホテルで開催予定である。半導体 技術業界を代表するこの国際会議のさらなる発展に期待し たい。 